\title{
ELŻBIETA EJANKOWSKA
}

Uniwersytet Rzeszowski

\section{POŁOŻENIE PRAWNE FILIAE FAMILIAS I JEJ UDZIAE W OBROCIE PRAWNO-GOSPODARCZYM PAŃSTWA RZYMSKIEGO W OKRESIE PÓŹNEJ REPUBLIKI I PRYNCYPATU (ZARYS PROBLEMATYKI)}

Tematem niniejszego opracowania są zagadnienia związane $\mathrm{z}$ aktywizacją ekonomiczną kobiet rzymskich na tle burzliwych przemian społeczno-politycznych okresu późnej republiki i ożywienia gospodarczego, które zapanowało w okresie pryncypatu'. Pole badań zostało jednak zawężone do problematyki obejmującej sytuację majątkową i udział w życiu gospodarczym kobiet, których status prawny określany był terminem filia familias. Ograniczenia wynikające $\mathrm{z}$ faktu podległości patria potestas zwierzchnika familijnego stawiały

' O sytuacji społeczno-ekonomicznej w okresie późnej republiki piszą G. AlFölDY, Historia spoteczna starożytnego Rzymu, przekł. A. GIERLIŃSKA, Poznań 1998, s. 533 i n.; M. CARY, H. H. SCullaRD, Dzieje Rzymu od czasów najdawniejszych do Konstantyna, przekł. J. SchwAKOPF, Warszawa 1992 (I, s. 364 i n.; II, s. 122 i n.); M. JACZYNOWSKA, Historia spoteczna starożytnego Rzymu, Warszawa 1984, s. 113 i n. Wnikliwa analiza transformacji polityczno-społecznej, która ma miejsce w okresie od I w. p.n.e. do końca pryncypatu, a była skutkiem przemian gospodarczych mających swój początek w czasach wojen punickich u F. DE MARTino, Storia della costituzione romana, IV. 1, Napoli 1962. Na temat rozwoju handlu w tym okresie por. L. Bove, Pratique du commerce et droit à Rome, «Index» 18 (1990), s. 223-228; P. HuVELIN, Études d'histoire du droit commercial romain, Paris 1929, s. 39 i n. 
je w sytuacji zdecydowanie niekorzystnej w porównaniu do Rzymianek sui iuris, które jakkolwiek podlegały opiece (tutela mulierum), to miały znaczny zakres samodzielności prawnej i gospodarczej². Trzeba jednak mieć na uwadze, że kobiety rzymskie, niezależnie od okresu rozwoju państwa, w którym przypadło im żyć, były formalnie wyłączone ze sfery życia publicznego i pozbawione części uprawnień $\mathrm{z}$ zakresu prawa prywatnego ${ }^{3}$. Ich sytuacja prawna najdobitniej została określona w wypowiedzi Papiniana: „W wielu przepisach naszego prawa położenie kobiet jest mniej korzystne, aniżeli mężczyzn"4. Unormowania prawne, których skutki w odniesieniu do kobiet tak trafnie określił jurysta, oznaczały w praktyce życia codziennego daleko posuniętą dyskryminację kobiet.

Jednakże przemiany społeczno-gospodarcze, które rozpoczęły się w drugiej połowie III w. p.n.e., będące jednym z następstw ekspansji terytorialnej Rzymu, zapoczątkowały wzrost znaczenia kobiet. Od tego czasu Rzymianki, chociaż pozbawione części praw obywatelskich, zaznaczały de facto swój udział w życiu publicznym 5 .

${ }^{2} \mathrm{Na}$ temat sytuacji prawno-majątkowej kobiet sui iuris por. np. W. KozUBSKI, Opieka nad kobietami w prawie rzymskim, Kraków 1922; S. SolazzI, Tutela, «NNDI» 19 (1973), s. 915 i n.; P. Bonfante, Corso di diritto romano, I: Diritto di famiglia, Roma 1925, s. 407 i n.; J. F. GARDNER, Being a Roman Citizen, London 1993, s. 88 i n.; TEJże, Women in Roman Law and Society, London-Sydney 1986, s. 14 i n. O przemianach w położeniu prawno-majątkowym kobiet sui iuris w ustawodawstwie dynastii julijsko-klaudyjskiej ostatnio M. ZABŁoCKA, Przemiany prawa osobowego i rodzinnego w ustawodawstwie dynastii julijsko-klaudyjskiej, Warszawa 1987, s. 94-112.

${ }^{3}$ D. 50,17,2 (Ulp.): Feminae ab omnibus officis civilibus vel publicis remotae sunt ... Por. też D. 15,1,12,2-3 (Paul.) i D. 16,1,1 (Paul.).

${ }^{+}$D. 1,5,9 (Pap.): In multis iuris nostri articulis deterior est condicio feminarum quam masculorum.

${ }^{5}$ Zagadnienia dotyczące udziału kobiet w życiu publicznym republiki rzymskiej są tematem pracy C. HERMANN, Le rôle iudiciaire et politique des femmes sous la République romaine, Bruxelles-Berchem 1964. Autorka ukazuje dzieje republiki akcentując „rebelianckie” postawy Rzymianek - w aspekcie długiej walki kobiet $\mathrm{z}$ antyfeministyczną polityką prowadzoną przez mężczyzn. Tę samą problematykę - w tonie bardziej zmoderowanym - przedstawia L. PEPPE w pierwszej części $(A l$ cuni elementi del modello femminile romano repubblicano) w swojej monografii $P o$ - 
Jedną z przyczyn ich aktywizacji społeczno- politycznej było niewątpliwie uzyskanie niezależności ekonomicznej, która była konsekwencją przejmowania przez kobiety - w drodze dziedziczenia majątków rodowych ${ }^{6}$. Te korzyści nie mogły być jednak udziałem kobiet należących do grupy filiae familias, gdyż nie miały one ex lege zdolności majątkowej. Najtrafniej określa to Gaius (G. 2,87): ... qui in potestate nostra est, nihil suum habere potest ... . To oznaczało, że w ustroju państwa rzymskiego, w którym warunkiem swobodnego udziału w życiu gospodarczym państwa była własność prywatna, kobiety podległe władzy familijnej nie mogły być jednostkami autonomicznymi w sensie ekonomicznym.

Dodatkowym utrudnieniem poza wymienionymi powyżej, z którymi ścierały się kobiety rzymskie na drodze do niezależności, bez względu na ich pozycję w obrębie rodziny, były względy kulturowe i społeczne. W państwie rzymskim zwłaszcza okresu republiki, kobieta była postrzegana jako żona i matka (mater familias) oraz pani domu (domina $)^{7}$. Z perspektywy XX-go wieku można uznać, że przypisywanie kobiecie takiej właśnie roli społecznej było w praktyce stosowaniem zasad sztywnego determinizmu biologicznego ${ }^{8}$. Jednak i w tej

sizione giuridica e ruolo sociale della donna romana in età repubblicana, Milano 1984. Ciekawe informacje dotyczące tego tematu podaje W. SCHULLER, Wprowadzenie do studium historii starożytnej, przekł. R. KulESZA, Warszawa 1997, s. 106 i n. Na temat wzrostu znaczenia kobiet w tym okresie por. też M. CARY, H. H. SCUllard, op. cit., I, s. 374 i n.; I. BIEŻUŃSKA-MAŁOWIST, Kobiety antyku. Talenty ambicje, namiętności, Warszawa 1993, s. 23 i n.

${ }^{6}$ Por. M. CARY, H. H. Scullard, op. cit., I, s. 374 i n.; J. F. Gardner, Women, cit., s. 176 i n.

${ }^{7} \mathrm{O}$ tym, jak szczególną wagę przywiązywali Rzymianie do samorealizacji kobiet w rolach przypisywanych im przez wielowiekową tradycję piszą J. CARCOPINO, $\dot{Z} y$ cie codzienne $w$ Rzymie $w$ okresie rozkwitu cesarstwa, przekł. M. PĄKCIŃSKA, Warszawa 1966, s. 106 i n.; C. Hermann, op. cit., s. 31; B. ŁaPICKI, Prawo rzymskie, Warszawa 1948, s. 118, 119 i 123; L. PEPPE, op. cit., s. 70 i n.

${ }^{8} \mathrm{Na}$ temat poglądów określanych terminem sztywnego determinizmu biologicznego (opierającego się na niepodważalności różnic między mężczyzną a kobietą) por. J. MizIELIŃSKA, Czy potrzebna jest akceptacja androgynii? Rozważania o tożsamości kobiet i mężczyzn, «Kwartalnik Pedagogiczny»11.2 (1966), s. 71-100, 
dziedzinie następowały zmiany światopoglądowe i obyczajowe, czemu sprzyjała powolna transformacja tradycyjnego, patriarchalnego modelu rodziny rzymskiej. Korzystały z tego przedsiębiorcze Rzymianki (a wśród nich i filiae familias) i, mimo że żyły w świecie zdominowanym przez mężczyzn, stopniowo zdobywały coraz większą samodzielność nie tylko w życiu społecznym, ale i gospodarczym.

Jedną z przyczyn tego swoistego procesu emancypacyjnego była często wieloletnia nieobecność mężów i ojców (patres familias) związana $\mathrm{z}$ ich udziałem w kampaniach wojennych. Sprawowanie przez nich władzy familijnej (zarówno potestas, jak i manus) ulegało wówczas praktycznemu zawieszeniu, co skutkowało rozluźnieniem się więzi rodzinnych i małżeńskich, a to sprzyjało wzrostowi samodzielności kobiet. Przemiany te nasiliły się zwłaszcza w czasie drugiej wojny punickiej, kiedy to doszło do wygaśnięcia linii męskiej w wielu rodzinach rzymskich?. Wówczas zarysowały się dwie różne tendencje w procesie usamodzielniania się kobiet:

1) Pierwsza $z$ nich dotyczyła kobiet ze stanu arystokratycznego i ekwickiego, które po śmierci swych zwierzchników familijnych dziedziczyły majątki dużej wartości i zyskiwały znaczną samodzielność ekonomiczną lub - jako podległe władzy - korzystały z fortun należących do ich mężów czy ojców. To owocowało nie zawsze korzystnymi zmianami w ich trybie życia i obyczajach jak np. lekkomyślność, rozrzutność, jaką wykazywały niektóre Rzymianki w korzystaniu z tych majątków, czy odstępstwo od tradycyjnej religii rzymskiej ${ }^{10}$.

a w szczeg., s. $72-73$ i literatura tam podana s. 72 przyp. 2; M. A. GLENDON, Spojrzenie na nowy feminizm, (przekł. W. OstrowsKI), «Więź» 40.1 (1998), s. 65-79, a w szczeg., s. 75.

' W okresie działań wojennych prowadzonych w latach 219-201 p.n.e. państwo rzymskie poniosło szczególnie duże straty w ludności, a zwłaszcza w stanie liczebnym wojska. M. CARY, H. H. SCULlaRd, op. cit., I, s. 252 piszą, że w czasach II wojny punickiej, zwanej „wojną światową czasów starożytnych” zginęło około 100000 żołnierzy. Por. też M. JACZYNOWSKA, op. cit., s. 95.

${ }^{10}$ Por. np. C. HermanN, op. cit., s. 52 i n. Na temat szerzenia się w Rzymie kultów wschodnich w latach II wojny punickiej i późniejszych piszą M. JACZYNOwSKA, op. cit., s. 191; M. KuryŁowiCZ, 'Loca aedilem metuentia'. (Sen. 'De vita beata', 
Politycy rzymscy próbowali zapobiec tym niekorzystnym zjawiskom, czego efektem było m.in. doprowadzenie do uchwalenia lex Oppia de luxu feminarum, skierowanej przeciwko wystawnemu trybowi życia kobiet, a następnie lex Voconia, której skutkiem było ograniczenie spadkobrania kobiet po testatorach z pierwszej klasy cenzusu majątkowego ${ }^{11}$. Rzymianki nie pogodziły się z próbą naruszania ich swobód ekonomicznych, czego wyrazem było wywarcie przez nie skutecznej presji na mężczyzn w celu uchylenia lex Oppia, a - w odniesieniu do lex Voconia - znalezienie sposobu na obejście jej przepisów.

Jak miało się okazać z czasem, wzrost niezależności ekonomicznej kobiet miał też korzystne następstwa. W ostatnim wieku republiki pojawiły się bowiem kobiety, które nie tylko kontrolowały zarząd własnych majątków, sprawowały nadzór nad gospodarstwem domowym, ale też pomagały swoim mężom w prowadzeniu działalności gospodarczej, a także wspierały ich w walce politycznej ${ }^{12}$.

7,1,3). Z dziatalności edylów rzymskich na rzecz ochrony porządku i moralności publicznej, «Annales UMCS», 32-33 (1985-1986), s. 123-135, a w szczeg. s. 130 wraz ze źródłami i podaną tam literaturą.

"Lex Oppia i lex Voconia należały do ustaw skierowanych przeciwko zbytkowi (leges sumptuariae). Ich zestawienie można znaleźć u Aulusa Gelliusa (2,24) i Macrobiusa (sat. 3,17). Na temat leges sumptuariae por. m.in. M. KuRYŁowICZ, 'Leges sumptuariae' w państwie rzymskim i prawie rzymskim, [w:] Z historii państwa, prawa i miast Polonii, Rzeszów 1998, s. 139-154 i podana tam ważniejsza literatura od 1970 r., s. 139-140; TENŻE, Prawo i obyczaje w starożytnym Rzymie, Lublin 1994, s. 43 i n.; TENŻE, Prawo i obyczaje, «RZN Prawo-Ekonomia» 29 (2000), s. 7-12; J. SondEL, Les 'leges sumptuariae' considerées comme l'expression des conditions sociales et économiques de la Rome antique, "Archiwum Iuridicum Cracoviense» 6 (1973), s. 101 i n.; J.F. GARDNER, Being a Roman, cit., s. 102 i n.; C. HERMANN, op. cit., s. 60 i n., wraz ze źródłami i podaną tam literaturą; A. PIKULSKA-ROBASZKIEWICZ, Ustawowa regulacja obyczajów w prawie rzymskim, «Studia Iuridica» 37 (1999), s. 213-219.

${ }^{12} \mathrm{Na}$ ten temat por. A. Kirschenbaum, Sons, Slaves and Freedmen in Roman Commerce, Jerusalem 1987, s. 124-125; S. TREgGiari, Jobs in the Household of Livia, «Papers of British School at Rome» 43 (1975), s. 48-77, a w szczeg. s. 63-64, źródła oraz literatura tam podana, s. 72, przyp. 151 i 153; F. ScHulz, Classical Roman Law, Oxford 1951, s. 184. 
2) Inny charakter miała emancypacja kobiet ze stanu plebejskiego. Jedną z jej głównych przyczyn były pogarszające się warunki życia tej warstwy społecznej ${ }^{13}$, które zmusiły plebejki do przejęcia na siebie częściowej lub całkowitej odpowiedzialności za stabilizację ekonomiczną rodziny. W praktyce oznaczało to podjęcie przez nie działalności zarobkowej. Jak wskazują źródła epigraficzne, kobiety te nierzadko pracowały zawodowo u boku swych mężów czy ojców, a po ich śmierci prawdopodobnie kontynuowały pracę w rodzinnych przedsiębiorstwach ${ }^{14}$. Ubogie Rzymianki wykonywały też zarobkowo te czynności, które tradycyjnie mieściły się w zakresie ich obowiązków domowych, jak np. przędzenie wełny, szycie i naprawa ubrań, czy karmienie niemowląt ${ }^{15}$.

Nowe możliwości zarobkowania dla kobiet z warstwy plebejskiej pojawiły się wraz ze zmianami, jakie następowały w życiu codziennym Rzymian już od początku II w. p.n.e. Bogaci obywatele rzymscy bowiem, ulegając wpływom hellenistycznym i orientalnym, korzystali z usług aktorek, tancerek, śpiewaczek oraz flecistek, które uświetniały swymi występami uroczystości domowe lub publiczne ${ }^{16}$.

${ }^{13} \mathrm{Na}$ ten temat por. G. Alföldy, op. cit., s. 129; F. De Martino, op. cit., s. 23 i n.; M. CARY, H. H. Scullard, op. cit., I, s. 585 i n.; T. ŁoposzKo, Zarys dziejów spoteczeństwa cesarstwa rzymskiego, Warszawa 1987, s. 7 i n. Zdaniem M. RoSTOVTZEFFA, Social and Economical History of the Roman Empire, I, Oxford 1963, s. 203 kryzys gospodarczy ostatniego półwiecza republiki najbardziej dotknął drobnych rzemieślników i kupców.

${ }^{14} \mathrm{Z}$ analizy inskrypcji (CIL: 6939; 9211; 9941; 37819; 37820; 37826) dokonanych przez S. Treggiari, Lower Class Women in the Roman Economy, «Florilegium» 1 (1979), s. 65-86, wynika, że kobiety wykonywały ten sam zawód, co ich mężowie lub ojcowie, bądź zajmowały się dystrybucją wytwarzanych przez nich wyrobów. Por. też J. F. GARDNER, Women, cit., s. 239; A. Kirschenbaum, op. cit., s. 124.

15 Por. np: Apul. met. 9,5; D. 15,1,27 pr. (Gai.); D. 24,1,28,1 (Paul.); D. $50,13,1,14$ (Ulp.).

${ }^{16}$ Por. K. KUMANIECKI, Historia kultury starożytnej Grecji i Rzymu, Warszawa 1987, s. 113 i n.; J. F. GARDNER, Women, cit., s. 246 i n. oraz źródła tam podane s. 255, przyp. 36; S. TRegGiari, Jobs for Women, «American Journal of Ancien History» 12 (1976), s. 76-104, a w szczeg. s. 90-91. 
Kobiety o niskim statusie społecznym były zatrudniane jako kelnerki lub zarządzające w różnego typu przedsiębiorstwach restauracyjnych. Wiele $z$ nich łączyło to zajęcie $z$ uprawianiem prostytucji bądź stręczycielstwa ${ }^{17}$.

Cechą wspólną tych dwóch jakże odmiennych nurtów przemian w położeniu Rzymianek był towarzyszący im liberalizm społeczno-obyczajowy, który był jednym $\mathrm{z}$ następstw załamania się monopolu mężczyzn w niektórych dziedzinach życia gospodarczego i społecznego. W konsekwencji liberalizm ten doprowadził do stopniowego upadku tradycyjnego modelu rodziny rzymskiej, chociaż nie zawsze wiązało się to ze zmianami w jej strukturze prawnej.

Używany w źródłach prawa rzymskiego termin filia familias $^{18}$ oznacza córkę podległą władzy swego ojca lub ojczystego ascendenta. Była ona jednym $z$ członków rzymskiej rodziny agnacyjnej, w której władzę zwierzchnią sprawował pater familias ${ }^{19}$. Status społeczno prawny każdego z członków rodziny zależał od pozycji, jaką zajmował on w jej strukturze prawnej. Stanowisko osoby alieni iuris przy-

${ }^{17} \mathrm{O}$ uprawianiu prostytucji przez kobiety zatrudnione w przedsiębiorstwach restauracyjnych piszą J. F. Gardner, Women, cit., s. 248-252; A. SoKala, 'Meretrix' i jej pozycja w prawie rzymskim, Toruń 1998, s. 29, przyp. 30 i s. 59-60; S. TREGGIARI, Lower Class Women, cit., s. 74-75. O stręczycielkach szerzej u A. SoKALI, 'Lenocinium' w prawie rzymskim, Toruń 1992, s. 19 i n. Por. też H. INSADOWSKI, Rzymskie prawo matżeńskie a chrześcijaństwo, Lublin 1935, s. 202-203; J. F. GARDNER, Women, cit., s. 133-134; S. TREgGIARI, Lower Class Women, cit., s. 73.

${ }^{18}$ Por. Vocabularium Iudisprudentiae Romanae, II, s. 853- 862; Vocabularium Codicis Iustiniani, I, s. 109-111. H. Heumann, E. SECKEL, s. v. 'filia familias', [w:] Handlexikon zu den Quellen des römischen Rechts, Graz 1958, s. 215; A. BERGER, Encyclopedic Dictionary of Roman Law, Philadelphia 1953, s. 472; CH. LEwIS, T. SHORT, A Latin Dictionary, Oxford 1955, s. 249; J. SonDEL, Stownik tacińsko-polski dla prawników i historyków, Kraków 1997, s. 83;

${ }^{19}$ Por. D. 50,16,195,2 (Ulp.): ... iure proprio familiam dicimus plures personas, quae sunt sub unius potestate aut natura aut iure subiectae ... Na temat tego źródła por. m.in. P. BONFANTE, op. cit., I, 8 i n.; A. BERGER, s. v. patria potestas [w:] Dictionary, cit., s. 621; G. FRANCIOSI, Famiglia e persone in Roma antica, dall'età arcaica al principato, Torino 1989, s. 7-8; G. LOBRANO, 'Pater et filius eadem persona', Milano 1984 , s. 28 i n. 
sługiwało w rodzinie agnacyjnej proprio iure jedynie zwierzchnikowi familijnemu. Osoby, które podlegały jego władzy (synowie, córki, wnuki i wnuczki patris familias pochodzące $\mathrm{z}$ małżeństwa podległego mu syna, jak też prawnuki i prawnuczki oraz żona syna $z$ tzw. małżeństwa cum manu), należały do kategorii alieni iuris. Jakkolwiek na przestrzeni wieków więź agnacyjna ulegała stopniowemu rozluźnieniu, to w okresie późnej republiki i pryncypatu władza ojcowska nadal zachowywała swój monokratyczny i patriarchalny charakter ${ }^{20}$. Łagodząco wpływała na nią jedynie praktyka życia codziennego i przywiązywanie przez Rzymian ogromnej wagi do jednej z najstarszych wartości etycznych, jaką była pietas (t. j. wzajemne zobowiązania członków rodziny do szacunku i wsparcia) ${ }^{21}$. Zmiany w strukturze prawnej rodziny rzymskiej następowały dość wolno, ale nie stało się to hamulcem dla stopniowego usamodzielniania się jej członków, a w tym również kobiet podległych władzy familijnej.

Status filiae familias przysługiwał kobietom, które urodziły się w małżeństwie ważnym według ius civile. Były to córki zwierzchnika familijnego, a także wnuczki z małżeństwa syna pozostającego pod jego władzą ${ }^{22}$. Drugim sposobem wejścia do rodziny agnacyjnej i za-

${ }^{20}$ Por. F. Schulz, Principles of Roman Law, Oxford 1956, s. 198 i n. Autor w konkluzji swoich rozważań stwierdza, że surowa władza ojcowska pozostała niezachwiana (the harsch patria potestas was steadfastly maintained). Podobnie D. Daube, Roman Law - Linguistic, Social and Philosophical Aspects, Edinburgh 1969 , s. 76 i n.

${ }^{21} \mathrm{Na}$ temat pietas por. R. P. SALLER, 'Pietas', Obligation and Authority in the Roman Family, [w:] Alte Geschichte und Wissenschaftsgeschichte. Festschrift für Karl Christ zum 65 Geburtstag, Darmstadt 1988, s. 393-410, a w szczeg., s. 395 i źródła tam powołane. W kontekście rozważań R. P. Sallera warto zwrócić uwagę na ujęcie pietas w pracy T. MIKOCKIEGO, Zgodna, pobożna, ptodna, skromna, piękna ... Propaganda cnót żeńskich $w$ sztuce rzymskiej, Warszawa 1977, s. 105 i n., które wydaje się najpełniej oddawać istotę tej wartości etycznej. Według autora: „... społeczno-rodzinny charakter tej personifikacji łączył się ściśle z religijnym, a bliski związek życia rodzinnego z politycznym w Rzymie przyczynił się do tego, iż pietas była uważana za jedną z najważniejszych rzymskich cnót”. Por. też W. LITEWSKI, Podstawowe wartości prawa rzymskiego, Kraków 2001, s. 25.

${ }^{22}$ G. 1,55; D. 1,6,3 (Gai.); D. 1,6,4 (Ulp.); D. 50,16,195,2 (Ulp.). 
jęcie stanowiska filiae familias było przysposobienie, ale tylko tzw. adoptio w sensie węższym, gdyż - w okresie późnej republiki i pryncypatu - kobiety nie mogły wejść pod patria potestas na skutek arrogatio (publiczno-prawnej formy przysposobienia). Arrogacja obywatelek rzymskich była bowiem niedopuszczalna aż do czasów Dioklecjana ${ }^{23}$.

Trzecim sposobem wejścia do rodziny agnacyjnej, dostępnym tylko dla kobiet, było zawarcie przez nie małżeństwa, które było połączone $z$ wejściem żony pod władzę męża lub jego zwierzchnika familijnego. W źródłach to zwierzchnictwo określane było terminem manus $^{24}$, a położenie prawno - majątkowe żony podległej manus było bardzo zbliżone do sytuacji filiae familias. Według Gaiusa w prawie spadkowym - żona zajmowała wówczas stanowisko córki agnacyjnej (filiae loco) wobec swojego męża lub wnuczki (neptis lo$c o$ ) wobec jego zwierzchnika familijnego ${ }^{25}$.

Konsekwencją tego, że filia familias należała do kategorii osób alieni iuris, był - w sferze stosunków majątkowych - brak jej zdolności majątkowej. Do końca republiki w położeniu ekonomicznym osób podległych władzy nie zauważa się znaczącego zróżnicowania, gdyż jedynym podmiotem praw majątkowych w rodzinie proprio iure był pater

${ }^{23}$ G. 1,97-107,134. Na temat adoptio obszernie M. KuRYŁowICZ, Die 'adoptio' in klassischen römischen Recht, Warszawa 1981; TENŻE, 'Adoptio' prawa rzymskiego. Rozwój i zmiany w okresie poklasycznym i justyniańskim, Lublin 1976, s. 30-31 co do autentyczności konstytucji Dioklecjana i Maksymiana (C. 8,47,8); C. Russo-RUGGIERI, La 'datio in adoptione', I: Origine, regime giuridico e riflessioni politico-sociali in età repubblicana ed imperiale, Milano 1990.

${ }^{24}$ G. 1,108-113; 2,159; 3,3; Cic., top. 3,14; Gell. 18,6,9. Na temat manus szerzej P. Bonfante, op. cit., s. 42 i n.; G. Franciosi, op. cit., s. 70 i n., oraz literatura tam podana s. 71 przyp. 77; W. RozWADOWSKI, Nowe badania nad istotq matżenstwa rzymskiego, «Meander» 42.4-5 (1987), s. 246 i n.; TENŻE, Prawo rzymskie. Zarys wykładu wraz z wyborem źródet, Poznań 1992, s. 204 i n.

${ }^{2 s}$ G. 1,111, 1,114; 1,115b; 1,118; 1,137a; 2,159; 3,3. Por. W. WoŁodKIEWICZ, M. ZabŁocka, Prawo rzymskie. Instytucje ${ }^{4}$, Warszawa 2005, s. 95 i n.; P. Bonfante, op. cit., s. 78; P. E. CORBETT, The Roman Law of Marriage, Oxford 1930 (przedruk 1979), s. 108 i n.; G. Franciosi, op. cit., s. 71; S. PEROzZI, Istituzioni di diritto romano, I, Milano 1947, s. 327; F. Schulz, CRL, s. 117; TENŻE, Principles, cit., s. 195-196. 
familias. Wyłom w uregulowaniach prawnych ius civile nastąpił dopiero w początkach pryncypatu, a został spowodowany wprowadzeniem instytucji peculium castrense, która umożliwiła synowi podległemu władzy zdobycie odrębnego majątku i rozporządzanie nim ${ }^{26}$. Warunkiem nabycia przez filius familias tego rodzaju zdolności majątkowej było pełnienie przez niego służby wojskowej. Natomiast filia familias pozostawała nadal w kręgu osób alieni iuris pozbawionych podmiotowości majątkowej. Osoby te nie mogły również zaciągać zobowiązań ważnych według ius civile ${ }^{27}$. Odmienna była sytuacja filii familias, który prawdopodobnie od końca republiki, a niewątpliwie w okresie pryncypatu mógł się zobowiązywać i być pozywanym, jakkolwiek zarówno egzekucja majątkowa, jak i osobista była tu bezskuteczna ${ }^{28}$.

Skoro w okresie późnej republiki i pryncypatu filia familias w przeciwieństwie do filii familias nie mogła własną mocą kształtować swoich stosunków prawnych, a zatem pozbawiona była autonomii prywatnej ${ }^{29}$, to można przypuszczać, że udział w społecznych

${ }^{26} \mathrm{Na}$ ten temat F. LA RosA, 'Peculium', «NNDI» 12 (1957), s. 755; TENŻE, I peculii speciali in diritto romano, Milano 1953, źródła i literatura tam powołana; P. BoNFANTE, op. cit., I, s. 98 i n.; D. DAUBE, Actions between 'pater familias' and 'filius familias' with 'peculium castrense', [w:] Studi in memoria di Emilio Albertario, I, Milano 1953, s. 433-474; TENŻE, Roman Law, cit., 77 i n.; F. SCHulz, CRL, s. 154-155.

${ }^{27}$ G. 3,104: ... et filia familias et quae in manu est non solum ipsi, cuius iuri subiecti subiectaeve sunt obligari non possunt, sed nec alii quidem ulli. Przekł. u W. Rozwadowskiego, 'Gai Institutiones'. Instytucje Gaiusa. Tekst i przektad, Poznań 2003, s. 121. Por. także D. 45,1,141,2 (Gai.), z którego wynika, że filia familias - po osiągnięciu dojrzałości - mogła zaciągać zobowiązania. W literaturze powszechny jest pogląd, że to kompilatorzy przypisali brak zdolności zobowiązywania się jedynie córce niedojrzałej. Na temat interpolacji tego tekstu, por. np.: M. GARCIA-GARRIDO, 'Ius uxorium'. El regimen patrimonial de la mujer casada en derecho romano, Roma-Madrid 1958, s. 7 i n.; R. MONIER, Manuel élémentaire de droit romaine, I, s. 258; F. SCHULZ, CRL, s. 157.

${ }^{28}$ Por. np. D. 13,63,4 (Ulp.); D. 46,4,8,4 (Ulp.). Na ten temat P. BONFANTE, op. cit., I, s. 93; R. MONIER, op. cit., I, s. 254; G. SCHERILlo, Corso di istituzioni di diritto romano, Milano 1984, s. 206; A. KIRSChEnBaum, op. cit., s. 58; F. SCHulz, CRL, s. 267.

${ }^{29} \mathrm{Na}$ temat autonomii prywatnej por. A. Wolter, J. Ignatowicz, K. STEFANIUK, Prawo cywilne. Zarys części ogólnej, Warszawa 2001, s. 33. 
formach wymiany dóbr i usług był dla niej nieosiągalny. Jednak dynamiczny rozwój społeczno - gospodarczy powodował stale pogłębiający się dysonans między sztywnymi uregulowaniami ius civile a życiem codziennym i praktyka okazała się inna.

Ważną formą udziału niewolników i osób alieni iuris w życiu gospodarczym Rzymu, która, w miarę rozwoju terytorialnego państwa i zwiększania się obrotu towarowo - pieniężnego coraz bardziej zyskiwała na znaczeniu, było gospodarowanie w oparciu o peculium. Nazwą tą określano wyodrębnione masy majątkowe, które, niezależnie od ich pochodzenia, stanowiły własność sprawującego władzę, a nawet przysługujące mu wierzytelności, jeżeli przekazał je podległemu władzy jako peculium ${ }^{30}$. Wobec braku zdolności majątkowej zarządców majątku pekuliarnego, miał on byt jedynie w sferze ekonomicznej, niemniej osoby te mogły podejmować czynności prawne dotyczące peculium ${ }^{31}$. Upoważnienie do tych działań wynikało $\mathrm{z}$ faktu powierzenia zarządu osobom wolnym lub niewolnikom podległym władzy tego, który jednocześnie był właścicielem majątku ${ }^{32}$. Jakkolwiek instytucja ta funkcjonowała w praktyce życia codziennego prawdopodobnie już w czasach ustawy XII tablic ${ }^{33}$, to

${ }^{30}$ D. $15,1,7,4$ (Ulp.): In peculio autem res esse possunt omnes mobiles et soli; vicarios quoque in peculio potest habere et vicariorum peculium; hoc amplius et nomina debitorum. Na temat tego źródła por. P. BonfanTE, op. cit., s. 152; I. ŻEBER, A Study of the 'peculium' of a Slave in Pre-Classical and Classical Roman Law, Wrocław 1981, s. 41.

${ }^{31} \mathrm{O}$ tym, że peculium było operacją natury ekonomicznej, a nie rozwiązaniem o charakterze prawnym, świadczą wypowiedzi Ulpiana (D. 15,1,5,4; D. 15,1,9,2-3). Na temat tych źródeł por. G. E. LoNGo, Diritto romano, III: Diritto di famiglia, Roma 1953, s. 142; I. ŻEBER, op. cit., s. 24 i n. Tam też na temat permissus domini jako jednego $\mathrm{z}$ najważniejszych elementów konstytuujących peculium. Por. też D. 41,2,49 (Pap.).

${ }^{32} \mathrm{O}$ upoważnieniu dla osób alieni iuris do dokonywania czynności prawnych w ramach peculium mówi Paulus (D. 15,1,45; Qui peculii administrationem concedit videtur permittere generaliter, quo et specialiter permissurus est.).

${ }^{33}$ Tab. 8,12: Sub hac condicione liber esse iussu, si decem (milia) heredi dederti, etui ab herede abalienatus sit, emptori dando pecuniam ad libertatem perveniet. Por. 
w dobie późnej republiki i pryncypatu stała się doskonałym rozwiązaniem praktycznym, które $\mathrm{z}$ jednej strony umożliwiało decentralizację zarządu majątkiem rodzinnym, a z drugiej - dawało faktyczną samodzielność ekonomiczną osobom alieni iuris i niewolnikom, którzy zarządzali peculium.

Jak wynika ze źródeł prawniczych i nieprawniczych, peculium było ustanawiane również dla filiae familias i prawdopodobnie dla uxor in manu, której położenie prawno-majątkowe było bardzo zbliżone do usytuowania córki rodziny ${ }^{34}$. Przedmiot peculium powierzanego kobiecie podległej władzy familijnej zależał od stopnia zamożności jej rodziny.

$\mathrm{Na}$ ogół były to niewolnicy, pieniądze, grunty, kosztowności rodzinne czy narzędzia do wykonywania pracy zarobkowej. Filia familias prowadziła działalność gospodarczą - tak jak inni zarządcy w granicach upoważnienia, które wynikało z samego aktu powierzenia peculium. Zatem, jeżeli zawierane przez nią zobowiązania nie wymagały upoważnienia szczegółowego, jej zwierzchnik familijny nie musiał być o nich poinformowany. Jednak gdy czynności te dotyczyły peculium handlowego, to konieczna była wiedza tego, którego władzy zwierzchniej podlegała kobieta ${ }^{35}$.

Liczba tekstów, w których jest mowa o peculium córki podległej władzy (chociaż nie zawsze jest ono określane tym terminem), w porównaniu $\mathrm{z}$ bogatym materiałem źródłowym dotyczącym majątku pekuliarnego niewolnika i syna rodziny, nie jest imponująca. $\mathrm{Z}$ tego faktu i z treści tych źródeł można wysnuć wniosek, że po-

przekł. u M. i J. ZAвŁOCKICH, Ustawa XII Tablic. Tekst-ttumaczenie-objaśnienia, Warszawa 2003, s. 48. Na temat związku tego przepisu z instytucją peculium (w świetle źródeł zawartych w D. 40,7 - de statuliberis) obszernie I. ŻEBER, op. cit., s. 55 i n.

${ }^{34}$ Por. D. 6,1,65,1 (Pap.); D. 15,1,27 pr. (Gai.); D. 15,3,20 pr. (Scaev.); D. 15,3,21 (Scaev.); D. 23,3,24 (Pomp) D. 37,7,8 (Pap.); D. 39,5,31,2 (Pap.); Frag. Vat. 255; 294; C. 4,12,3; C. 5,18,7; Plaut., cas. 190, 22-31 (uxor in manu).

${ }^{35}$ D. 15,1,27 pr. (Gai.): ... sed et tributoriam actionem, si quo peculiari merce sciente patre dominove negotientur dandam esse ... 
wodem ustanowienia peculium dla filiae familias nie były konieczności natury gospodarczej, lecz przyczyny rodzinne i społeczne. Zarządzanie częścią majątku familijnego i korzystanie z wypracowanych dochodów, pozwalało córce rodziny na pewną samodzielność ekonomiczną, a zarazem umożliwiało nabywanie umiejętności gospodarowania pod kierunkiem zwierzchnika familijnego. Było to szczególnie ważne dla kobiet podległych władzy familijnej w rodzinach swego pochodzenia, ale zamężnych; powodowało bowiem ich uniezależnienie - na płaszczyźnie ekonomicznej - od męża bądź jego zwierzchnika familijnego.

W świetle ius civile czynności niewolników i osób alieni iuris były ważne, jeżeli ich skutkiem było nabycie korzyści majątkowych, które, wobec braku zdolności majątkowej podległych, przypadały dzierżycielom władzy nad nimi, natomiast ci ostatni nie byli odpowiedzialni za długi kontraktowe osób in potestate $e^{36}$. Taka sytuacja nie zachęcała kontrahentów spoza kręgu rodzinnego do zawierania transakcji z podległymi władzy, co z kolei musiało wpływać hamująco na dynamikę obrotu gospodarczego. Dlatego rozwiązaniem tego problemu zajęli się pretorowie, którzy już od połowy II w. p.n.e. zaczęli zamieszczać w edykcie powództwa $z$ tytułu czynności zawieranych przez osoby podległe władzy. Te skargi (określane w średniowieczu przez glosatorów jako actiones adiecticiae qualitatis) umożliwiały kierowanie roszczeń wynikających ze zobowiązań zaciągniętych przez osoby alieni iuris i niewolników przeciwko tym, którzy sprawowali nad nimi władzę ${ }^{37}$. Jakkolwiek pretorowie uregulowali tylko niektóre dziedziny działalności gospodarczej, a odpowiedzialność zwierzchnika familijnego zawsze była jakimś stopniu ograniczona, to faktycznie umożliwili oni na szeroką skalę aktywizację ekonomiczną niewolników i osób alieni iuris.

\footnotetext{
${ }^{36}$ D. 41,1,10,1 (Gai.); D. 50,17,133 (Ulp.); G. 1,152; 2,87; 3,104.

${ }^{37}$ Por. też G. 4,69-74a. Formuly tych powództw są zamieszczone w rekonstrukcji edyktu pretorskiego O. LENELA, Das 'Edictum Perpetuum'. Ein Versuch zu seiner Wiederstellung ${ }^{3}$, Leipzig 1927, s. 257-282.
} 
Jak wynika ze źródeł, powództwa te - przynajmniej w okresie prawa klasycznego - przysługiwały także z powodu transakcji zawieranych przez filia familias. Dyrektywę ogólną w tej kwestii stanowi wypowiedź Ulpiana dotycząca klauzuli edyktu pretorskiego odnoszącej się do trzech skarg: actio de peculio, actio de in rem verso i actio quod iussu.

D. 15,1,1,1-3 (Ulp. 29 ad ed.): Est autem triplex hoc edictum aut enim de peculio aut de in rem verso aut quod iussu hinc oritur actio. 2. Verba autem edicti talia sunt: „Quod cum eo, qui in alterius potestate esset, negotium gestum erit." 3. De eo loquitur, non de ea: sed tamen et ob eam, quae est et feminini sexus dabitur ex hoc edicto actio.

Jurysta przyznaje, że w klauzuli jest mowa o osobie płci męskiej, a nie żeńskiej. Niemniej jednak uważa, że każde z tych powództw można wytoczyć również $\mathrm{z}$ powodu prowadzenia spraw wobec osób trzecich (negotium gestum) przez kobiety. Znajduje to potwierdzenie w innych tekstach, $\mathrm{z}$ których wynika, że przesłanki stosowania tych skarg były analogiczne, jak w przypadku niewolnika i syna rodziny. Jedynie actio de peculio, w odniesieniu do filiae familias, pełniła także inną funkcję; była odpowiednikiem actio rerum amotarum w sytuacji, gdy żona podlegała władzy swego zwierzchnika familijnego ${ }^{38}$.

Analiza źródeł dotyczących powództw o charakterze dodatkowym wskazuje, że córka podległa władzy mogła rozwijać działalność gospodarczą nie tylko na bazie peculium, czy w granicach udzielonego upoważnienia, ale też jako zarządca (institor), wyodrębnionej placówki gospodarczej, która nie stanowiła jej peculium. Wówczas wierzycielom filiae familias przysługiwała actio institoria przeciwko sprawującemu nad nią władzę ${ }^{39}$. Brak źródeł z których mogłoby wynikać, że córka podległa władzy była usta-

\footnotetext{
${ }^{38}$ Por. np.: D. 25,2,3,4 (Paul); D. 13,1,19 (Paul); D. 15,1,13,12 (Ulp.); D. 25,2,3,5 (Pap.).

${ }^{39}$ D. $14,3,7,19$ (Ulp.); PS. 2,8,1.
} 
nawiana armatorem lub kapitanem statku oznacza, że w praktyce mało prawdopodobne było stosowanie actio exercitoria $\mathrm{z}$ powodu działalności filiae familias ${ }^{40}$.

W ścisłym związku $\mathrm{z}$ kwestią gospodarowania filiae familias w majątku pekuliarnym pozostaje actio tributoria, która zasadniczo była udzielana wierzycielom w sytuacji, gdy córka prowadziła - za wiedzą sprawującego nad nią władzę - działalność handlową w oparciu o peculium lub jego częśćc ${ }^{41}$.

W świetle omówionych powyżej regulacji prawa pretorskiego wydaje się, że kobieta podległa władzy familijnej miała - w sensie normatywnym - takie same możliwości prowadzenia działalności gospodarczej jak niewolnicy i synowie rodziny. $\mathrm{Na}$ przeszkodzie stanęły jednak uwarunkowania kulturowe, polityczne i społeczno-gospodarcze, które spowodowały, że udział filiae familias w obrocie prawno-gospodarczym miał znacznie mniejszy zasięg niż niewolników i synów podległych władzy.

Być może z perspektywy współczesnych kobiet żyjących w kręgu kultury eurocentrycznej, wydaje się, że zakres samodzielności społecznej i gospodarczej jaką zdobyły kobiety rzymskie, a wśród nich filiae familias jest dość skromny. Trzeba jednak mieć na uwadze, że nie mogły one walczyć o równouprawnienie, ani tym bardziej o uprzywilejowaną pozycję w strukturach społeczno - politycznych androcentrycznego Rzymu, gdyż poziom świadomości każdej grupy czy warstwy społecznej jest zależny przede wszystkim od warunków bytowych i czasowych, w których ona egzystuje. Dlatego nieomal pompatyczne i groteskowe wydaje się interpretowanie wzrostu ich aktywności społeczno - gospodarczej w kategoriach feministycznych. Nurt określany jako „wolnościowy” i „równościowy” pojawił

${ }^{40} \mathrm{Z}$ zestawienia D. 14,1,1,19 (Ulp.) i D. 14,1,1,21 (Ulp.) można wyprowadzić wniosek, że możliwe było ustanowienie filiae familias armatorem. Jednak brak źródeł, z których mogłoby bezpośrednio wynikać, że takie sytuacje miały miejsce, nie pozwala na rozwijanie tej tezy.

${ }^{41}$ Por. D. 14,4,1,4 (Ulp.); D. 14,4,5,2 (Ulp.) - argumentum a minori ad maius; D. 15,1,27 pr. (Gai.). 
się bowiem dopiero w dobie wielkiej rewolucji francuskiej (178999) oraz amerykańskiej wojny o niepodległość (1775-83) i wówczas dołączyły do niego kobiety ${ }^{42}$. Nie można też zapominać, że możliwości aktywizacji zawodowej i gospodarczej kobiet oraz szanse na ich awans edukacyjny i społeczny pojawiły się dopiero w kapitalizmie, natomiast w Rzymie - nawet w okresie największego rozkwitu gospodarczego - nie doszło do rozwoju stosunków kapitalistycznych ${ }^{43}$. Rzymianki zatem wykorzystały dziejową szansę na stopniowe włączenie się do życia społeczno - ekonomicznego państwa. Jak wykazała analiza źródeł prawniczych i literackich, kobiety podległe władzy zwierzchnika familijnego, mimo że w świetle ius civile były pozbawione podmiotowości majątkowej i autonomii prywatnej, mogły faktycznie - podobnie jak niewolnicy - mieć wpływ na swoje położenie ekonomiczne. Dlatego uczestnictwo w obrocie gospodarczym filiae familias musiało zataczać coraz szersze kręgi i mimo że dominującą rolę odgrywali niewolnicy i synowie rodziny, to zaznaczały one swą obecność na płaszczyźnie prawno - gospodarczej. Nawet jeżeli prowadziły swą działalność na obrzeżach życia ekonomicznego Rzymu, to ślady tej działalności dowodzą, że filiae familias zaistniały w obrocie prawno-gospodarczym, czego następstwem było uzyskanie przez nie w pewnym zakresie samodzielności ekonomicznej i de facto tworzyła im dogodne warunki do samorealizacji i kreowania własnej rzeczywistości, co nie mogło nie pozostawić wpływu na procesy socjalizacji kolejnych pokoleń Rzymianek.

\footnotetext{
${ }^{42} \mathrm{Na}$ ten temat szerzej A. JASIŃSKA, Dylematy feminizmu, [w:] Nikt nie rodzi się kobieta, Warszawa 1982, s. 313 i n.

${ }^{43} \mathrm{Na}$ ten temat por. F. DE Martino, op. cit., s. 279 i n., który uważa, że w I w. n.e. podstawą gospodarki było rolnictwo i handel, zaś produkcja przemysłowa miała znaczenie drugorzędne. Tam też ostra krytyka stanowiska, które zajmują zwolennicy poglądu, jakoby ówczesne stosunki społeczno-gospodarcze miały charakter kapitalistyczny. Według G. ALFÖLDY’EGo, op. cit., s. 137 w Rzymie nie doszło do wykształcenia nowego, a nawet wczesnokapitalistycznego systemu ekonomicznego, gdyż „szerokie masy ludności nie odczuwały potrzeby zapewnienia sobie wystarczającego wyżywienia oraz pełnego zatrudnienia".
} 
LEGAL SITUATION OF THE FILIAE FAMILLAS AND ITS SIGNIFICANCE IN LEGAL and Commercial Transactions in tHe Roman STATE DURING the Period of the Late Republic and Principate (AN OUTLINE OF THE ISSUES)

\section{Summary}

The legal and economic situation of the filiae fanilias is presented against the background of political and social-economic changes in two different political systems of the state, the common characteristics of which were that they constituted consecutive stages of advanced Roman civilization. The period faced an increase in the significance of women, although - regardless their status familiae - they were formally excluded from the public life and deprived of certain rights in the domain of private law. Nevertheless, social and economic changes, resulting from the territorial expansion of Rome, made it possible for Roman women to expand their activities beyond the scope of the matters related to every day existence, family and religion, which traditionally for centuries had been considered as a women's domain.

As far as the social aspect of Roman women's activities is concerned, their status familiae seemed to be of no major importance. As regards commercial aspects, the situation was different. In this respect, the sui iuris women unquestionably enjoyed richer possibilities. Nevertheless, as the analysis of legal and literary sources show, women subject to the authority of a family superior - although having no possibility to be carriers of property rights or to enjoy private autonomy - could in fact influence their economic situation, similarly to slaves. It was possible mainly due to peculium that stemmed from the common law, which played a significant role in the social - economic life of the Roman state.

It was of a particular significance in the case of women who were subject to familial authority, but were married. This resulted from the fact that managing a trust property and using the earned income made it possible for women to enjoy certain economic freedom, and, as a consequence, become independent of her husband or his family superior. 
Undoubtedly, the expansion and diversification of the activities of filiae familias were influenced by the actiones adiecticiae qualitatis, which uniformly regulated the responsibilities of the holders of authority for the liabilities of the alieni iuris persons and slaves. Moreover, parties to contracts with the family could file such claims, as the aforesaid sources have proved, which meant that the praetor's law offered a guarantee that they could pursue such claims before courts. Consequently, the participation of women subject to familial authority in commercial transactions had to become wider. Although still a dominant role was played by the family's slaves and sons, women were present in the legal and economic field during periods of the Late Republic and the Principate. 